\title{
Broiler breeding flocks: management and animal welfare
}

Ingrid C. de Jong and Rick A. van Emous, Wageningen Livestock Research, The Netherlands

1 Introduction

2 Housing conditions and management in the rearing period

3 Housing conditions and management in the production period

4 Welfare issues: restricted feeding and water restriction

5 Welfare issues: excisions, mating behaviour and quality of feather cover

6 Environmental enrichment

7 Vaccinations

8 Transgenerational effects

9 Concluding remarks

10 Where to look for further information

11 References

\section{Introduction}

This chapter discusses the management of broiler breeders, that is, the parent stock of broiler chickens, and welfare issues related to the different life stages of broiler breeders. Where commercial broilers are the product of a cross of four lines, broiler parent stock (broiler breeders) are the product of a cross of two lines; both the male and female broiler breeder is the product of a cross of a specific paternal line and a specific maternal line (Hiemstra and Ten Napel, 2013). The actual figures on the number of broiler breeders worldwide are lacking; as an indication, in Europe the number of broiler breeders is estimated to be 44 million (Horne and Bondt, 2014). Management and housing of grandparents and great grandparents (but not pedigree stock) is to a large extent similar to that of broiler breeders (EFSA, 2010; Hiemstra and Ten Napel, 2013) and not described in this chapter. Nowadays, three companies dominate the world market for broiler breeding stock: Aviagen Broiler Breeders, Cobb-Vantress and Hubbard.

The majority of the broiler breeders worldwide are the parent stock of the so-called standard or fast growing broilers, which reach a body weight of $2.5 \mathrm{~kg}$ in 42 days or 
less (EFSA, 2010). Dwarf parental females are used to produce broilers of intermediate (2.2 kg in 56-63 days of age) or slow growth rate (2.2 kg in 70-80 days of age) (De Jong and Swalander, 2013). Although worldwide only a small percentage of parent stock for intermediate or slow growing broilers is housed, in some countries a larger proportion of the total number of broiler breeders produce intermediate or slower growing broiler strains. For example, in France, the majority of the parent stock $-85 \%$ according to De Jong and Guemene (2011) - are parents of intermediate or slower growing broiler strains (EFSA, 2010). In Europe, about $8 \%$ of the broiler breeders are estimated to be parent stock of intermediate or slower growing broilers (Horne and Bondt, 2014).

We provide a short, general description of housing and management of broiler breeders during both the rearing and the production period in the next paragraph. In addition, we focus on (major) welfare issues related to the management of broiler breeders and the current state-of-the-art research related to these welfare issues.

\section{Housing conditions and management in the rearing period}

In the rearing period, which comprises the age between 0 and 18-22 weeks, broiler breeder pullets are prepared for the production phase. The aim of the rearing period is to produce birds of ideal weight, uniformity, condition and stage of sexual maturity when they enter the production house (Leeson and Summers, 2000). Body weight and flock uniformity are important production indicators during the rearing period (Zuidhof et al., 2015).

Although there is worldwide variation in housing conditions during the rearing period due to differences in legislation, climatic conditions and labour costs, layout of rearing houses does not vary to a large extent. During the rearing period, broiler breeders are usually housed on a fully littered floor, and litter types vary between regions due to availability. In Europe, wood shavings, peat and straw are commonly used. Cage rearing is not common (De Jong and Swalander, 2013; EFSA, 2010). Feed is either distributed via pan feeders, chain feeders or spin feeders (systems that spread the feed in the litter) and can be provided as mash, crumb or pellet. Pelleted feed should be used in combination with spin feeders. Parent stock of fast growing broiler chickens is subjected to feed restriction during the rearing period (De Jong and Guemene, 2011; EFSA, 2010). In addition, water provision may be restricted (Hocking et al., 1993). Feed can be either provided daily or a skip-a-day feeding regime may be applied (EFSA, 2010). Skip-a-day feeding regimes can be in the form of $6 / 1,5 / 2$ or $4 / 3$ feeding programmes (1, 2 or 3 days without feed each week and a larger portion on the feeding days). In Europe, usually daily feeding applied as legislation does not allow skip-a-day feeding programmes. Either raised platforms or perches are provided, usually from about 6 weeks of age onwards, to train the birds to use the higher levels in a house during the production period.

Depending on the region, climate and legislation, houses can be fully climate controlled and without daylight entrance or with windows, or either open-sided with mesh curtains. Males and females are reared separately so that different feeding programmes can be applied in rearing. Stocking density also varies between countries, depending on the climatic conditions and also on country-specific legislation. In European countries, stocking densities between 7 and $10 \mathrm{birds} / \mathrm{m}^{2}$ (females) or 4 and $8 \mathrm{birds} / \mathrm{m}^{2}$ (males) are generally applied, with lower stocking densities in open-sided houses (EFSA, 2010). After 


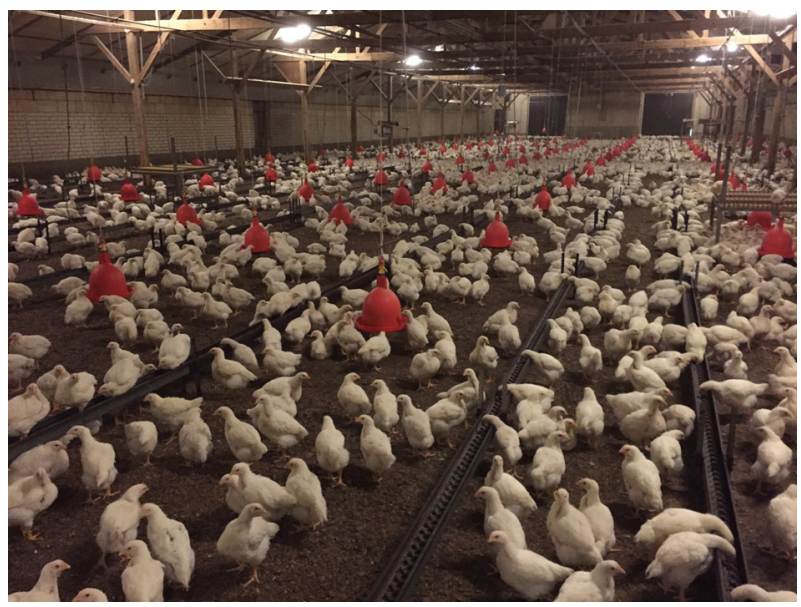

Figure 1 Example of a broiler breeder rearing house in northwest Europe (photo provided by N. Katier).

a few days, usually a light programme with $8 \mathrm{~h}$ light per day is applied with a light intensity between 10 and 20 lux, although lower light intensities may be applied in case of injurious pecking or to reduce birds' activity (EFSA, 2010). The management guides of the breeding companies are usually taken as the basis for stocking density, light programme, feeding programme and so on (e.g. Aviagen, 2013; Cobb, n.d.; Hubbard, n.d.). Figure 1 shows an example of a rearing house in northwest Europe.

\section{Housing conditions and management in the production period}

The main goal in broiler breeder production is to provide fertilised eggs to produce a maximum number of healthy and robust day-old broiler chicks (Zuidhof et al., 2007). Important in relation to the management of adult breeders is maintaining the health status of the flock while keeping the egg production at a high level. Major criteria for monitoring birds for management purposes include body weight, body condition, egg production and hatching, hatchability and infertility and egg weight (Leeson and Summers, 2000).

The transition from the rearing period to the production period involves transportation to the production house, usually at a separate production farm. The production period starts between 18 and 22 weeks and lasts until 60-65 weeks, depending on the performance of a breeder flock. Males and females are reared separately and mixed at the beginning of the production period, and in Europe usually arrive on the same day at the production farm (EFSA, 2010; Van Tuijl, Aviagen, 2016, pers. comm.). The majority of the breeders are housed in floor house systems during the production period. Houses may be artificially lit, with or without windows or open-sided with curtains, which is dependent on legislation, region and climate. Artificial light in addition to natural light can be used to stimulate reproduction. Although less common, broiler breeders can also be housed in multi-tier colony cages during the production period. These are furnished cages with laying nests, 
perches and also a small litter area (De Jong and Swalander, 2013). Aviaries are not used for broiler breeders. During the production period broiler breeders can also be housed in conventional cages where artificial insemination is applied; this is uncommon in Europe, but may be found in other parts of the world (EFSA, 2010).

Floor house systems consist of a litter area and a certain proportion of slatted floors from which the nests can be accessed. The proportion of littered floor versus raised slatted floor (plastic or wooden slats) may differ between countries and regions, and the layout is also regionally dependent. Water is usually supplied on the slatted area and feed may be provided on the litter and/or on the slatted area. Litter types may vary between countries, for example, wood shavings, straw or peat. Feed can be provided in various forms (mash, pellet and crumbs) via feeder tracks or pans containing a male exclusion system. Male breeders are usually fed via trough feeding or feeder pans near the walls of the house, at such a height that the female breeders cannot reach there. Water can be provided via nipples, bell drinkers or cups. Feed restriction is applied during the production period to control the body weight, but the restriction level is much less severe as compared to the rearing period (De Jong and Jones, 2006). Water restriction may also be applied (EFSA, 2010). Figure 2 shows an example of a production house in northwest Europe.

Stocking density during the production period varies between 5 and $7.5 \mathrm{birds} / \mathrm{m}^{2}$ depending on the legislation and region. Stocking density is usually lower in open-sided houses (EFSA, 2010). The percentage of males at the start of the production period is between 8 and 11\%, and this decreases due to selection and mortality of males. At the start of the production around 23 weeks of age, 7.5-9\% males are present in a flock (EFSA, 2010). The selection criterion of male breeders includes absence of mating activity and health problems (e.g. leg problems). About 15-25\% of the males are selected during the production period. In some countries, 'spiking' of males is common practice. Inactive males are removed from the flock and replaced by younger and more active males to maintain the production of fertile eggs at a high level (Leeson and Summers, 2000). However, spiking involves the risk of introduction of pathogens and it may be stressful

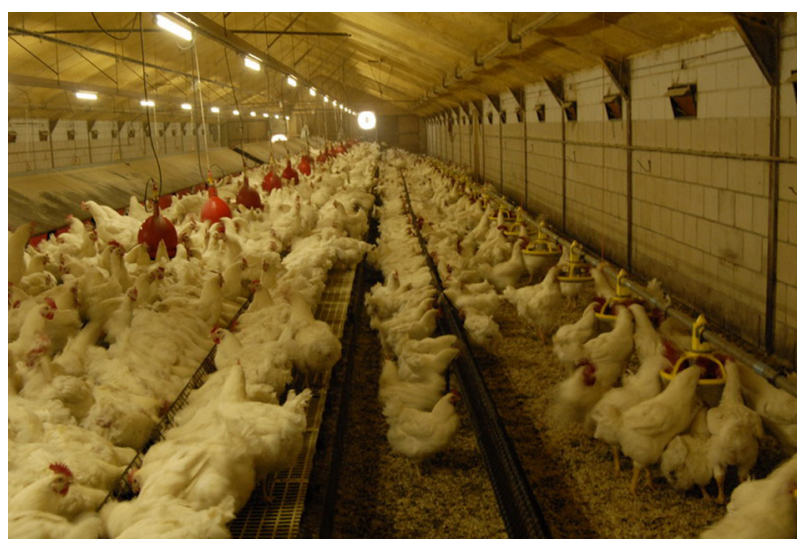

Figure 2 Example of a broiler breeder production house. Laying nests and slatted floors are present in the middle of the house (left side of the picture) and the litter area is at both sides of the slatted area near the walls. This house does not have windows (Photo: R. van Emous). 
to the birds because male aggression may increase (EFSA, 2010). Sometimes intraspiking (swapping older males at the same farm from one house to the next) is used as a method to increase male activity and thus fertility, which has a much lower biosecurity risk (Casanovas, 2000).

\section{Welfare issues: restricted feeding and water restriction}

\subsection{Restricted feeding}

Parent stock of the so-called fast growing broilers (broilers that will reach a body weight of $2.5 \mathrm{~kg}$ in about 6 weeks) is subjected to restricted feeding programmes so that the birds will grow according to the growth curve as indicated by the breeding company. If broiler breeders are fed unrestricted, they will grow very fast, reach high body weights and as a result develop health (e.g. leg problems and increased mortality) (Heck et al., 2004; Mench, 2002) and reproduction problems. Low egg production associated with multiple ovulations, accelerated sexual maturity, low egg quality and low persistency of lay have been reported in unrestricted fed broiler breeders (Heck et al., 2004; Hocking et al., 1989), which is unfavourable with respect to the sustainability of the breeding flock. The high growth rate when fed unrestricted is due to the genetic selection for fast and efficient growth of standard, fast growing broiler chickens (Dawkins and Layton, 2012; Renema et al., 2007). Parent stock of so-called slower growing broiler strains are usually subjected to different, less restricted or unrestricted feeding programmes, as these birds have (much) slower growth rates due to a different genetic background (De Jong and Guemene, 2011). Parent stock of these so-called slower or intermediate growing broilers may either be a combination of a slower growing, usually dwarf female and a standard, fast growing male (that is subjected to a restricted feeding programme) or a combination of both a slower growing male and female.

Researchers in the early 1990s described the effect of the restricted feeding programme in broiler breeders on the welfare of the birds. Restricted fed broiler breeders show behavioural signs of stress and frustration, that is, redirected oral behaviours resulting in stereotypic object pecking (and if directed at the drinker resulting in overdrinking), hyperactivity, pacing (stereotypic walking) (De Jong et al., 2002; Hocking, 1993; Hocking, Maxwell and Mitchell, 1993; Hocking et al., 1996; Savory and Maros, 1993; Savory et al., 1992, 1993, 1996), increased aggression (Jones et al., 2004) and increased feeding motivation (Savory and Lariviere, 2000). It has also been reported that physiological indicators of (chronic) stress were observed, such as increased plasma corticosterone levels and increased heterophil:lymphocyte ratios in the blood (De Jong et al., 2003; Hocking, 1993; Hocking, Maxwell and Mitchell, 1996; Savory and Mann, 1997). However, more recently it has been debated if these physiological indicators indeed reflect stress, frustration and/or hunger in the birds or merely reflect the metabolic state (D'Eath et al., 2009; De Jong et al., 2003). Research continued with the aim to find reliable methods to measure hunger and motivation for appetitive behaviour in broiler breeders. A test was developed to measure appetitive behaviour (Dixon et al., 2014), but thus far no reliable behavioural test to assess hunger has been developed (Buckley et al., 2011a,b, 2015). Nevertheless, there is little doubt 
in research that animals undergoing quantitative feed restriction are hungry and that this negatively affects the welfare of the bird (D'Eath et al., 2009).

During the first 2-3 weeks of the rearing period, feed is provided unrestricted and thereafter a restricted feeding programme is started. The period in which the most severe restriction is applied starts around 6-7 weeks of age and runs to 15-16 weeks of age (De Jong and Jones, 2006). Restriction levels were estimated to be $25-33 \%$ of the intake of broiler breeders fed ad libitum (De Jong et al., 2002), but there are no recent data on relative restriction level. It can be expected that due to the continuing selection for efficient growth of the progeny, the relative restriction level has been increased since then (Zuidhof et al., 2014). By the end of the rearing period, that is, from 16 weeks of age onwards, the daily feed allowance slightly increases to prepare the birds for the production period. In addition, during the production period restricted feeding is applied, but restriction levels are much less severe as compared to the rearing period. Restriction levels of 45-80\% of the ad libitum intake are applied until the peak of lay (Bruggeman et al., 1999) and restriction levels to about $80 \%$ of ad libitum intake are applied after peak of lay (Hocking et al., 2002), although also here no recent data are available.

The majority of research with respect to welfare of broiler breeders is related to the effects of restricted feeding on welfare. More recently, research focused on various methods to reduce the negative effects of restricted feeding such as using alternative feed composition or alternative feeding methods. The results of these studies are discussed below.

\subsubsection{Fibre diluted diets or low protein diets in the rearing and the production period}

It has been shown that increasing the fibre contents of the diet or decreasing the energy and protein contents of the diet can have positive effects on the welfare of broiler breeders, as measured by a reduction in time spent on behaviours indicative of frustration, stress or hunger. Hocking et al. (2004) applied diets diluted with 50, 100 and $200 \mathrm{~g} / \mathrm{kg}$ ground oat hulls, ground unmolassed sugar beet pulp or sunflower meal and showed that diets with the highest concentration of oat hulls and sugar beet pulp had positive effects on behaviour during the rearing period (decreased prevalence of damaging pecking behaviour). The diets diluted with sugar beet pulp were associated with higher water content in the gastrointestinal tract and the authors suggested that these diets improved satiety and thus had the largest effect on the welfare of broiler breeders (Hocking et al., 2004).

De Jong et al. (2005a) applied diets with increased fibre contents and various fibre types in the rearing and the production period $(8.4 \mathrm{MJ} / \mathrm{kg}$ (standard diet) vs 9.2 and 10.4 MJ/kg diets in the rearing period, and $11.7 \mathrm{MJ} / \mathrm{kg}$ (standard diet) vs 9.2 and 10.5 $\mathrm{MJ} / \mathrm{kg}$ during the production period). They observed that the diet of $8.4 \mathrm{MJ} / \mathrm{kg}$ had some positive effects on the behaviour during the first half of the rearing period (decreased prevalence of stereotypic object pecking), but not during the second half of the rearing period, and even seemed to increase stress during the production period (indicated by a higher heterophil:lymphocyte ratio in the blood in the production period). Sandilands et al. (2005) and Tolkamp et al. (2005) fed broiler breeders ad libitum with diets diluted with oat hulls but in addition used an appetite suppressant $(400 \mathrm{~g} / \mathrm{kg}$ oat hulls or $400 \mathrm{~g} / \mathrm{kg}$ oat hulls and $24-110 \mathrm{~g} / \mathrm{kg}$ calcium propionate added to the standard diet, depending on bird's age) or used calcium propionate in combination with low protein content and provided these diets ad libitum $(150 \mathrm{~g} / \mathrm{kg}$ crude protein vs $200 \mathrm{~g} / \mathrm{kg}$ crude protein in 
the standard diet vs diets diluted with oat hulls or oat hulls in combination with calcium propionate (Sandilands et al., 2006)). Stereotypic pecking was virtually absent, time spent sitting significantly increased and feeding motivation was reduced when applying diets diluted with oat hulls and including an appetite suppressant, indicating that welfare of broiler breeders during the rearing period might be improved (Sandilands et al., 2005; Tolkamp et al., 2005). The same effects on behaviour during the rearing period were found when appetite suppressants were used in combination with low protein diets (Sandilands et al., 2006). Morrissey et al. (2014b) showed that diets with increased fibre content (soy bean hulls, $400 \mathrm{~g} / \mathrm{kg}$ ) and an appetite suppressant (calcium propionate, 10-50 g/ $\mathrm{kg}$ ) had a positive effect on the behaviour of broiler breeders in the rearing period. However, it can be questioned if the use of appetite suppressants will be accepted by society; in addition, researchers questioned if the effects of appetite suppressants are caused by the fact that birds feel ill (Hocking and Bernard, 1993), which is unfavourable in terms of animal welfare.

Nielsen et al. (2011) tested the effects of diets with a high proportion of soluble or insoluble fibre. Three diets were applied, a commercial diet with non-starch polysaccharides (NSP) as fibre content ( $80 \%$ insoluble fibres) and two diets with twice the fibre content and a higher $(89 \%)$ or lower $(71 \%)$ proportion of insoluble fibres. They found that the experimental diet with twice the fibre amount and the high proportion of insoluble fibres had a positive effect on the behaviour of broiler breeders in the rearing period; stereotypic pecking was absent and more dust bathing, comfort behaviour and foraging was observed in these birds as compared to the control diet and the diet with soluble fibres. The diet with the low proportion of insoluble fibres negatively affected the litter quality (increased moisture level as compared to the other treatment groups) and birds fed these diets showed behavioural signs of discomfort. Thus, this diet was not preferred in terms of broiler breeder welfare (Nielsen et al., 2011). Others tested diets diluted with insoluble and soluble fibres (cellulose, wheat bran and cottonseed meal) during the production period and found that not only eating time increased, but that for the diets with insoluble fibres (cellulose and wheat bran) egg production also increased and plasma corticosterone concentrations decreased as compared to the diet diluted with cottonseed meal (Moradi et al., 2013), indicating a positive effect of these types of diluted diets on broiler breeder welfare and production.

Van Emous et al. (2014, 2015a) investigated the effects of three dietary protein levels and different growth patterns ( $2400 \mathrm{~g}$ vs $2200 \mathrm{~g}$ at 20 weeks of age) on indicators of welfare during the rearing and the production period. A positive effect on welfare indicators was found for the low dietary protein level diet in the rearing period, but not of the high growth pattern; stereotypic object pecking in the rearing period was significantly reduced in the low dietary protein treatment as compared to the other diets (van Emous et al., 2014, 2015a). When these diets in the rearing period were followed by a low, standard or high energy diet in the production period, it was shown that the low energy diet had a slightly positive effect on behavioural indicators of stress during the production period as compared to the medium or high energy diet, although both the low energy and low protein diet had negative effects on the quality of the feather cover. The authors concluded that increasing the energy:protein ratio had a positive effect on broiler breeder welfare as indicated by the behaviour of the pullets, especially in the rearing period (van Emous, 2015a).

To conclude, modifications of the diet composition by increasing the fibre level and/or increasing the energy:protein ratio are promising to alleviate the effects of feed restriction 
on broiler breeder welfare, especially during the rearing period. This research area needs further attention to promote application of these types of feed in practice.

\subsubsection{Feeding programmes, feeding frequencies and feeding methods}

In Europe daily feeding is commonly applied, whereas in North America skip-a-day feeding programmes are applied as these improve flock uniformity (de Beer and Coon, 2007). A few studies focused on the effects of daily or skip-a-day feeding programmes during the rearing period on broiler breeder welfare. Morrissey et al. (2014b) did not find evidence that either skip-a-day feeding (feeding on alternate days) or daily feeding differed in the extent to which broiler breeders were hungry or frustrated during the rearing period, although during the production period there seemed to be a positive effect of skip-a-day feeding over daily feeding (improved feather condition ascribed to less feather pecking) (Morrissey et al., 2014a). Skinner-Noble and Teeter (2009, cited in (EFSA, 2010)) reported no differences in stress levels in birds fed either daily or as per the skip-a-day feeding programme.

De Jong et al. (2005b) tested whether increasing the feeding frequency from once to twice a day, or scattering feed in the litter would reduce stress or hunger in the rearing period. They did not find any positive effects of both these methods on the behaviour and physiological indicators of stress. In general, it is advised to use mash feed instead of pellets to increase feeding time in broiler breeders, although this has not any effect on feelings of hunger. Furthermore, it is important to provide sufficient space at the feeders to prevent aggression in the birds at the time of feeding, as aggression around feeding may result in increased levels of feather and skin damage. Finally, the speed to which feed is distributed is very important to promote equal feed consumption between individuals, to promote flock uniformity and to prevent aggression between birds.

\subsubsection{Feeding of males}

Studies on the effect of feed restriction on broiler breeder welfare usually focus on the females, as there are numerically much more females present than male broiler breeders. According to Renema et al. (2007), males are subjected to a less severely restricted feeding regime during the rearing period as compared to females, but males are relatively more restricted during the production period as compared to females (EFSA, 2010). It is generally considered that feed restriction affects male welfare to a similar extent as the females; however, research is needed to confirm this hypothesis. De Jong et al. (2011) observed male and female broiler breeder behaviour during the rearing period when housed at two stocking densities (standard vs reduced stocking density), and observed that general behaviour of the males differed from female behaviour at both stocking densities. Object pecking was less common in male breeders as compared to female breeders during the rearing period, and males showed more standing and walking behaviour as compared to females. It is not clear if these differences in general behaviour imply a different stress level in males and females or just express differences in general behaviour between both sexes.

\subsubsection{Parent stock of slower growing broilers}

Substitution of the standard broiler breeders with dwarf or slower growing broiler breeders may be a strategy to improve welfare of broiler breeders during the rearing 
period (Decuypere et al., 2006). Jones et al. (2004) showed that replacing standard broiler breeders with dwarf female breeders favourably changed the behaviour (e.g. less stereotypic pecking), because the degree of food restriction during the rearing period was much less in the dwarf breeders as compared to the standard breeders. The dwarf breeders concern only one sex (only females), but numerically many more broiler breeder females are subjected to feed restriction as compared to males, and thus using dwarf females may be a solution for a large part of the broiler breeder population to improve welfare. However, using slower growing or dwarf females corresponds only to a specific market demand and in practice these bird types are not used on a large scale (De Jong and Guemene, 2011).

\subsection{Water restriction}

Farmers may apply water restriction during the rearing and the production period (starting from a few weeks of age onwards), although in some countries this is forbidden (EFSA, 2010). Water restriction is usually applied to prevent overdrinking in restricted fed broiler breeders, which may result in wet litter and, in severe cases, in polydipsia (Hocking et al., 1993). When water restriction is applied, water is usually provided around feeding and during a few hours after feeding, and possibly on other occasions during the day (EFSA, 2010). Water restriction is generally considered unfavourable with respect to welfare, although Hocking et al. (1993) showed that limited access to water during the rearing period of broiler breeders did not affect welfare indicators.

\section{Welfare issues: excisions, mating behaviour and quality of feather cover}

\subsection{Excisions (beak trimming, toe clipping and de-spurring)}

Depending on country-specific legislation, excisions can be carried out in broiler breeders. These are beak trimming (which can be applied in both males and females), toe clipping and de-spurring. EFSA (2010) reported that comb dubbing is only practised in less than $10 \%$ of the breeder population and not recommended by the breeders. Excisions can be carried out at the hatchery (de-spurring, toe clipping or beak trimming (applying hot blade) or infrared beak treatment (Gentle and McKeegan, 2007) or on-farm (hot blade beak trimming). Although toe clipping is commonly applied (usually the backward or inner toe is trimmed), de-spurring is not applied in all breeds (EFSA, 2010) and beak trimming is prohibited in some EU countries (Fiks-van Niekerk et al., 2009).

Both de-spurring and toe clipping are carried out to prevent feather and skin damage in the females due to mating behaviour of the males. Sharp and long spurs and toes may damage the feathers and subsequently the skin, and in flocks with non-mutilated males this can result in severe wounds in the females (and as a consequence increased mortality and a negative effect on egg production and fertility). This has especially been reported for males with intact toes (De Jong, 2016, pers. comm.). Beak trimming is performed in female and male broiler breeders to prevent feather and skin damage due to injurious pecking behaviour. Beak trimming in males also reduces feather damage at the back of the head, where the male grabs the female with his beak while mating (Gentle and McKeegan, 
2007). However, beak trimming in males and females is not practised in all countries and in general injurious pecking (feather pecking and resulting cannibalism) is not very common in broiler breeder flocks with intact beaks. Specific management might be required, such as providing pecking substrates (bales, pecking blocks) or, in case of an outbreak of injurious pecking, managing the light intensity.

In a pilot study on a commercial broiler breeder farm, it was found that females (Ross 308) with intact beaks had better performance during the rearing period than infrared beak-trimmed females. This was due to the fact that there was no negative effect of beak treatment on feed and water intake during the first days on the rearing farm, resulting in improved growth and uniformity and less mortality in the non-beak-trimmed as compared to the beak-trimmed flocks. Feather scoring during the rearing and the production period showed that in general there was no negative effect of non-beak trimming on the feather cover in flocks with intact beaks (De Jong et al., 2013). A pilot study in commercial flocks with non-beak-trimmed and beak-trimmed males (Ross 308; both housed with non-beaktrimmed Ross 308 females) showed that non-beak trimming of male broiler breeders also did not result in any negative effects on feather damage in females and males, nor was there an effect on the technical results of these flocks (De Jong, Gunnink and Van Emous, 2016, pers. comm.). It is currently unknown if there are differences between broiler breeder lines in the propensity to develop injurious pecking behaviour.

\subsection{Mating behaviour}

Mating behaviour of both males and females is important with respect to maximising the production of fertile eggs. However, broiler breeder males may show rough, aggressive behaviour towards females during mating. This rough male behaviour may lead to feather and skin damage and fearfulness in females. As a result, females may hide in the nests and fertility will be negatively affected (Millman et al., 2000). One of the reasons for male aggression may be that males reach maturity earlier than females, leading to forced copulations and distress in the females, which in turn results in females hiding on the slats and in the nests (Leone et al., 2007). However, also with proper management in relation to sexual development of males and females, rough and aggressive mating behaviour of the males has been observed. In addition, it was observed that courtship behaviour in males was virtually absent (De Jong et al., 2009; Hocking and Bernard, 2000; Jones and Prescott, 2000; Millman et al., 2000). It has also been observed that females do not seem to respond properly (with crouching behaviour) to male approach (De Jong et al., 2009).

It is unknown why male broiler breeders show this rough behaviour towards females during mating. Rough mating behaviour was not related to aggressive behaviour per se (Millman and Duncan, 2000b) and feed restriction in the rearing period was not related to rough mating behaviour (Millman and Duncan, 2000a). Genetic background may play a role, as males from laying strains responded less aggressive during mating than broiler breeder males (Millman and Duncan, 2000b). Reducing the stocking density, thus, providing males with more space to perform courtship behaviour, indeed had a positive effect on the quality of the mating behaviour (more courtship behaviour and more successful matings) and also resulted in a higher egg production, more fertile eggs and a higher number of chicks per hen (De Jong et al., 2011). Jones et al. (2001) showed that enriching the light conditions with $U_{A}$ improved the transmission of sexual signals and thus the quality of the mating behaviour. 


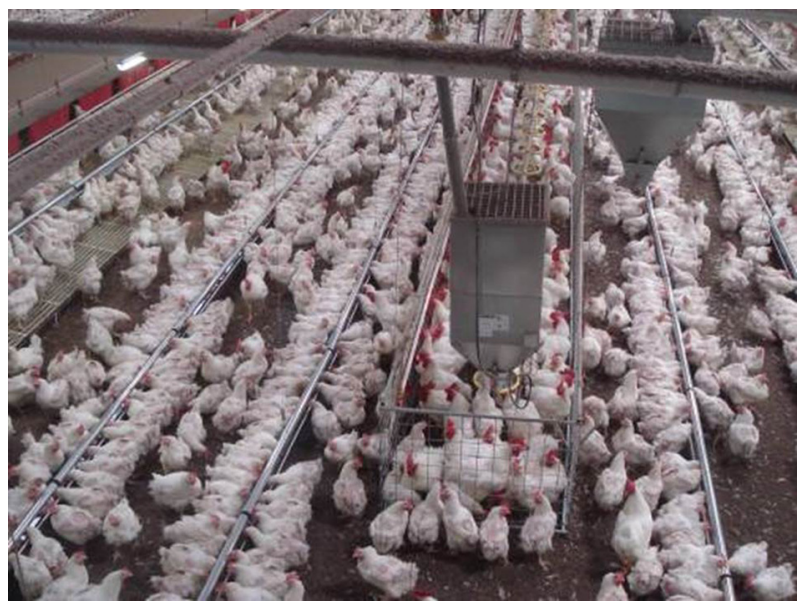

Figure 3 Quality Time broiler breeder house. Males are penned in a separate area during feeding (central area on the picture) (Photo: R.A. van Emous).

It has been estimated that mating frequency is 5-10 times higher in a broiler breeder house as compared to flocks of chickens housed under natural conditions (Van Emous, 2010). This relatively high frequency of mating may affect the relationship between the males and females, resulting in females avoiding males as hypothesised by Fontana et al. (1992). Over-mating might be avoided by separating females and males temporarily during the day. Based on this hypothesis, a new housing system for broiler breeders, called the Quality Time ${ }^{\circledR}$ Concept (QTC), has been developed (Van Emous, 2010). Males are separated from females during 5 hours/day, using a separate feeding system and a moving fence. After a successful pilot experiment, two on-farm experiments were carried out in a broiler breeder house with 15000 birds. The house was divided in six compartments. In the QTC compartments more voluntary and successful matings were observed. In addition, quality of the sexual behaviour improved, which resulted in an improved feather cover between 37 and 48 weeks of age in the QTC compartments as compared to the control compartments. Separating males from females did not increase aggressive behaviour between the males in the male pen (Van Emous, 2010).

As indicated in the current paragraph, management practices to improve mating behaviour and thus welfare of broiler breeders exist, with concurrently improved performance of the breeder flocks. These methods need to be further developed for practical application.

\subsection{Quality of the feather cover}

Quality of the feather cover, especially during the production period, is important with respect to the prevention of skin damage in females resulting from male mating behaviour and with respect to thermoregulation of the bird. However, quality of the feather cover has decreased during the past 10-20 years due to unknown reasons (Van Emous and De Jong, 2013). Figure 4 shows examples of a deteriorated feather cover in females in the second half of the production period. 


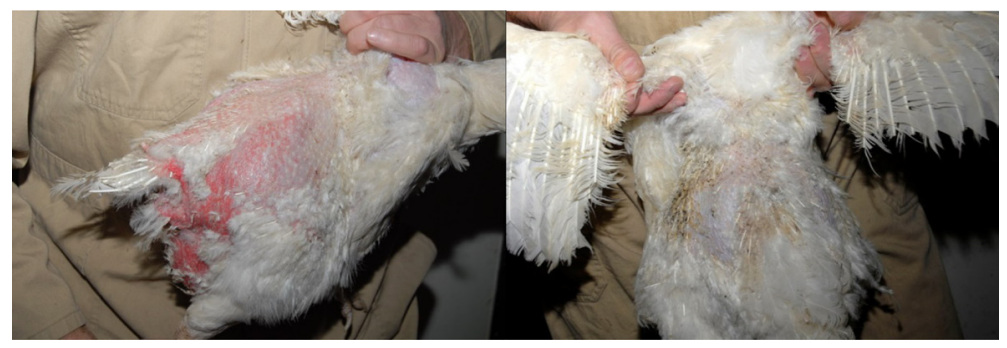

Figure 4 Examples of a deteriorated feather cover in female broiler breeders in the second half of the production period (Photo: R.A. van Emous).

Although not performing mutilations in broiler breeders implies an increased risk for a deteriorated feather cover (and skin damage), as indicated earlier, non-beak trimming of males and females did not seem to have a negative effect on the feather cover of both males and females (De Jong et al., 2013; De Jong, Gunnink and Van Emous, 2016, pers. comm.). Reduction of the stocking density improved the quality of the feather cover both in the rearing and in the production periods, although in general females at both standard and reduced stocking density still had a deteriorated feather cover at the end of the production period (De Jong et al., 2011).

Van Emous et al. $(2014,2015 a)$ studied the effect of diets with different protein content in the rearing period and different energy content in the production period on the quality of the feather cover. They concluded that a low daily protein intake during the rearing period and during first phase of the production period resulted in an inferior feather cover as compared to diets with medium or high protein content at these ages (see Van Emous et al., 2014, 2015a for diet composition tables). This indicates that specific amino acids levels for feather development were deficient. The authors also suggested that a low daily protein intake between 2 and 6 weeks of age showed a more pronounced effect on feather cover than a low daily protein intake between 6 and 15 weeks of age.

\section{Environmental enrichment}

It is well known that chickens prefer a high and safe resting place to roost at night-time, due to the motivation to protect themselves from predators. Usually in the rearing period, raised slatted areas $\left(\sim 1 \mathrm{~m}^{2} / 1000\right.$ birds) are provided from six weeks onwards to train the birds to go to the higher level, to prepare them to easily enter the nesting area during the production period. However, it is yet unclear if raised slatted areas might function as high and safe resting places or if breeders prefer perches. In addition, how these perches should be provided, including material and shape, is yet unclear. Most studies on perch design and perch use are carried out in laying hens, but it needs to be studied if results from the studies regarding laying hens are also valid for broiler breeders. A Swedish study, comparing wooden A-shaped perches with platforms, found a high incidence of breast blisters in the broiler breeders on perches which was not found in birds provided with platforms (Wachenfelt and Berndson, 2014). This could be due to the material and 
shape of the perches. In addition, they observed a preference of the birds to rest on the platforms, but this could have been influenced by birds experiencing pain due to the breast blisters and thus not using the perches (Wachenfelt and Berndson, 2014). Other studies only recorded that perches were used by broiler breeders, with increasing use with age (Hocking and Jones, 2006; Van Emous, 2016, pers. comm.). Further study is required to find whether perches or platforms are preferred by broiler breeders and which design should be applied when using perches. It is known from the studies regarding laying hens that a high proportion of birds in non-cage systems may suffer from keel bone fractures and deformities, caused by collisions with housing structures or prolonged pressure on the keel bone during perching (Heerkens et al., 2016). It is not known if broiler breeders suffer from keel bone fractures and keel bone deviations due to the design of perches and platforms.

Hocking and Jones (2006) studied if environmental enrichment, by providing plasticcoated bales of wood shavings or bunches of string, could decrease aggressive pecking and feather damage in broiler breeders in the rearing period. It turned out that plasticcoated bales of wood shavings, but not strings, were attractive for the breeders. However, neither behavioural changes nor improved feather cover were observed in the groups where enrichment was provided as compared to the control groups without enrichment.

Vertically placed cover panels in the litter area in the production house can be used to control excessive mating problems in commercial farms (Estevez, 1999) and thus may improve female broiler breeder welfare during the production period. In addition, cover panels improved reproductive performance in broiler breeder flocks, probably by attracting females to the litter floor and reducing male-male competition for females and over-mating (Leone and Estevez, 2008).

In general, environmental enrichment is not commonly applied in broiler breeder houses. Because environmental enrichment may improve the behavioural opportunities and reduce problematic behaviours such as injurious pecking (Estevez, 2009), further research to find appropriate enrichment for broiler breeders both in the rearing and in the production periods is needed.

\section{Vaccinations}

Maintaining flock health at a high level is an important issue during the rearing and the production period. Farmers usually apply a strict hygiene regime and disease prevention is an important issue with respect to flock management (EFSA, 2010). The applied vaccination schedule is dependent on country, region, individual farmers or advisers and integrations. However, during the rearing period broiler breeders can be subjected to a series of vaccinations starting at the hatchery or even in ovo. Examples are Marek's disease and infectious bronchitis (IB) vaccination at the hatchery, and vaccinations against Newcastle disease, IB, infectious laryngotracheitis (ILT), infectious rhinotracheitis, Gumboro, Salmonella and Escherichia coli at various ages in the rearing period. In the production period, broiler breeders are subjected to less frequent vaccinations (e.g. against (B), although this is also farmer or integration dependent. Vaccinations can be provided in various forms, such as injections, spray/aerosol, via drinking water and eye drops. Despite the need to prevent diseases in the breeder flock, (multiple) vaccinations 
are a challenge for the birds, resulting in depressed feeding (and thus growth) or local inflammation (Steentjes, 2016, pers. comm.).

\section{Transgenerational effects}

A relatively unknown area is how conditions during the life of broiler breeders affect the welfare and technical performance of the progeny. It is well known that age of the breeders is related to egg quality and chick quality, and first week mortality is higher in broilers from young breeding flocks (Yassin et al., 2009). However, it is important to consider that other conditions, for example, stress or diseases, in the life of the breeders may also affect the performance and welfare of the progeny. From laying hen studies it is known that feather pecking and anxiety in the layer breeding flock is related to the prevalence of feather pecking and anxiety in the progeny, although these effects were dependent on the genotype of the birds. The underlying mechanism may act through the deposition of corticosterone in the yolk of the eggs (de Haas et al., 2014).

Van der Waaij et al. (2011) studied the progeny of 60-week-old female broiler breeders that were either fed the recommended amount of feed or fed ad libitum during a 5 -week period. The offspring of breeders fed ad libitum was heavier than the offspring of restricted fed breeders. In addition, female offspring of restricted fed breeders were lighter at hatching, but were heavier and had more abdominal fat at six weeks of age than female offspring of the ad libitum fed breeders. These results suggested a possible transgenerational effect of the feeding regime in breeders on the broilers. However, more research is needed to further explore this relationship, as reviewed by Berghof et al. (2013), who focused on possible transgenerational effects of stress in breeders on innate immunity in broiler chickens. They suggested that the mismatch between the breeder and broiler environment (e.g. by diet composition or microbiota) may negatively affect the innate immunity in the broiler chickens, but that more research is needed to further unravel the underlying mechanisms.

With respect to the effect of feed composition in the production phase of the breeders and its influence on the progeny, there is some evidence that low-density diets $(21 \%$ lower nutrient density as compared to the standard diet) positively affect egg composition (higher egg white proportion) and hatchability, especially in young breeders (Enting et al., 2007b). The same authors found that these low-density broiler breeder diets improved growth rate of the progeny, reduced broiler mortality and either reduced or increased immune responses, depending on the breeder's age and egg weight (Enting et al., 2007a). It is not clear if these effects are due to transmission of nutrients from the breeder to the egg and the progeny, or to reduced stress in the breeders, or both.

Van Emous et al. (2015b) also studied the combined effects of low protein diets and different growth patterns in the rearing period on offspring performance. In general, they only found marginal effects of the different protein contents on progeny performance. However, male broilers of breeders fed the low protein diet during the rearing period had higher breast meat yield as compared to broilers of broiler breeders fed the medium or high protein diet - see Van Emous et al. (2015b) for diet composition tables. The effects of different daily protein intake of breeders during the rearing and the production period on progeny performance were observed in a consecutive experiment (van Emous et al., 2015a). A lower mortality and improved technical performance were observed in the 
progeny of 53-week-old breeders fed a low daily protein intake during the second phase of the laying period.

To conclude, there is evidence for transgenerational effects of management of broiler breeders and their progeny. This area needs further exploration to improve welfare and performance of both breeders and broilers.

\section{Concluding remarks}

The majority of the broiler breeders worldwide are parent stock of standard, fast growing broiler chickens. Because of the genetic selection for fast growth in the progeny, broiler breeders need to be subjected to restricted feeding programmes, especially during the rearing period. This is, despite a number of studies focusing on the methods to alleviate the negative effects of feed restriction on the welfare, still one of the most important welfare issues in broiler breeders. However, using feeds with higher insoluble fibre contents or lower protein content in the rearing period as compared to the standard commercial diets seems promising in terms of alleviating the effect of feed restriction on welfare. Another alternative is the use of slower growing or dwarf female broiler breeders that do not need to be fed restricted. Apart from feed restriction, other areas that need more attention in research are the relationship between management in the production period and mating behaviour, provision of environmental enrichment and how breeder management affects offspring performance.

\section{Where to look for further information}

Further information on housing and management can be found in management guides of the breeding companies that are updated on a regular basis (Aviagen, 2013; Cobb, n.d., Hubbard, n.d.) and textbooks (Leeson and Summers, 2000). Specific welfare issues have been discussed in various review papers (e.g. Decuypere et al., 2006, 2010; De Jong and Guemené, 2011) and the EFSA Scientific Opinion on welfare aspects of the management and housing of the grandparent and parent stocks raised and kept for breeding purposes (EFSA, 2010).

\section{References}

Aviagen. 2013. Ross parent stock management handbook. http://en.aviagen.com/assets/Tech_ Center/Ross_PS/Ross_PS_Handbook_2013_i-r1.pdf (Accessed date 24 March 2016).

Berghof, T. V. L., H. K. Parmentier and A. Lammers. 2013. Transgenerational epigenetic effects on innate immunity in broilers: An underestimated field to be explored? Poultry Science 92:2904-13.

Bruggeman, V., O. Onagbesan, E. D'Hondt, N. Buys, M. Safi, D. Vanmontfort, L. Berghman, F. Vandesande and E. Decuypere. 1999. Effects of timing and duration of feed restriction during rearing on reproductive characteristics in broiler breeder females. Poultry Science 78:1424-34.

Buckley, L. A., L. M. McMillan, V. Sandilands, B. J. Tolkamp, P. M. Hocking and R. B. D'Eath. 2011 a. Too hungry to learn? Hungry broiler breeders fail to learn a Y-maze food quantity discrimination task. Animal Welfare 20:469-81. 
Buckley, L. A., V. Sandilands, P. M. Hocking, B. J. Tolkamp and R. B. D'Eath. 2015. Feed-restricted broiler breeders: State-dependent learning as a novel welfare assessment tool to evaluate their hunger state? Applied Animal Behaviour Science 165:124-32.

Buckley, L. A., V. Sandilands, B. J. Tolkamp and R. B. D'Eath. 2011b. Quantifying hungry broiler breeder dietary preferences using a closed economy T-maze task. Applied Animal Behaviour Science 133:216-27.

Casanovas, P. 2000. Management techniques to improve male mating activity and compensate for the age-related decline in broiler breeder fertility: Intra-spiking. Cobb Technical News 7:1-8.

Cobb, undated. Cobb500FF Breeder Mangement Supplement. http://www.cobb-vantress.com/ docs/default-source/cobb-500-guides/cobb500ff-breeder-mangement-supplement---(english) 3CA513F5C35A.pdf (Accessed date 24 March 2016).

D'Eath, R. B., B. J. Tolkamp, I. Kyriazakis and A. B. Lawrence. 2009. 'Freedom from hunger' and preventing obesity: the animal welfare implications of reducing food quantity or quality. Animal Behaviour 77:275-88.

Dawkins, M. S. and R. Layton. 2012. Breeding for better welfare: genetic goals for broiler chickens and their parents. Animal Welfare 21:147-55.

de Beer, M. and C. N. Coon. 2007. The effect of different feed restriction programs on reproductive performance, efficiency, frame size, and uniformity in broiler breeder hens. Poultry Science 86:1927-39.

Decuypere, E., V. Bruggeman, N. Li Everaert, R. Yue Boonen, J. De Tavernier, S. Janssens and N. Buys. 2010. The broiler breeder paradox: ethical, genetic and physiological perspectives, and suggestions for solutions. British Poultry Science 51(5): 569-79.

Decuypere, E., P.M. Hocking, K. Tona, O. Onagbesan, V. Bruggeman, E.K.M. Jones, S. Cassy, N. Rideau, S. Metayer, Y. Jego, J. Putterflam, S. Tesseraud, A. Collin, M. Duclos, J. J. Trevidy and J. Williams. 2006. Broiler breeder paradox: a project report. World's Poultry Science Journal 62:443-53.

de Haas, E. N., J. E. Bolhuis, B. Kemp, T. G. G. Groothuis and T. B. Rodenburg. 2014. Parents and early life environment affect behavioral development of laying hen chickens. Plos ONE 9. doi 10.1371/journal.pone.0090577.

De Jong, I. C., H. Enting, S. Van Voorst, E. W. Ruesink and H. J. Blokhuis. 2005a. Do low density diets improve broiler breeder welfare during rearing and laying? Poultry Science 84:194-203.

De Jong, I. C., M. Fillerup and H. J. Blokhuis. 2005b. Effect of scattered feeding and feeding twice a day during rearing on parameters of hunger and frustration in broiler breeders. Applied Animal Behaviour Science 92:61-76.

De Jong, I. C. and D. Guemene. 2011. Major welfare issues in broiler breeders. World's Poultry Science Journal 67:73-81.

De Jong, I. C., H. Gunnink and R. A. Van Emous. 2013. Monitoring van onbehandelde vleeskuikenmoederdieren op een praktijkbedrijf. 21 pp Wageningen UR Livestock Research, Lelystad, Report 716.

De Jong, I. C. and R. B. Jones. 2006. Feed restriction and welfare in domestic birds. In V. Bels (ed.), Feeding in Domestic Vertebrates, pp. 120-35. CABI publishing, Wallingford, UK.

De Jong, I. C., A. Lourens, H. Gunnink and R. A. Van Emous. 2011. Effect of stocking density on (the development of sexual behaviour and technical performance in broiler breeders. $61 \mathrm{p}$. Wageningen UR Livestock Research, Lelystad, Report 457.

De Jong, I. C. and M. Swalander. 2013. Housing and management of broiler breeders and turkey breeders. In V. Sandilands and P. M. Hocking (eds), Alternative Systems for Poultry: Health, Welfare and Productivity, pp. 225-49. CABI publishing, Wallingford, UK.

De Jong, I. C., S. Van Voorst and H. J. Blokhuis. 2003. Parameters for quantification of hunger in broiler breeders. Physiology \& Behavior 78:773-83.

De Jong, I. C., S. Van Voorst, D. A. Ehlhardt and H. J. Blokhuis. 2002. Effects of restricted feeding on physiological stress parameters in growing broiler breeders. British Poultry Science 43:157-68. 
De Jong, I. C., M. Wolthuis-Fillerup and R. A. Van Emous. 2009. Development of sexual behaviour in commercially-housed broiler breeders after mixing. British Poultry Science 50:151-60.

Dixon, L. M., S. Brocklehurst, V. Sandilands, M. Bateson, B. J. Tolkamp and R. B. D'Eath. 2014. Measuring motivation for appetitive behaviour: food-restricted broiler breeder chickens cross a water barrier to forage in an area of wood shavings without food. Plos ONE 9. doi 10.1371/ journal.pone.0102322.

EFSA. 2010. Scientific Opinion on welfare aspects of the management and housing of the grandparent and parent stocks raised and kept for breeding purposes. The EFSA Journal 8:81. doi doi:10.2903/j.efsa.2010.1667.

Enting, H., W. J. A. Boersma, J. B. W. J. Cornelissen, S. C. L. van Winden, M. W. A. Verstegen and P. J. van der Aar. 2007a. The effect of low-density broiler breeder diets on performance and immune status of their offspring. Poultry Science 86:282-90.

Enting, H., T. A. M. Kruip, M. W. A. Verstegen and P. J. van der Aar. 2007b. The effect of low-density diets on broiler breeder performance during the laying period and on embryonic development of their offspring. Poultry Science 86:850-6.

Estevez, I. 1999. Cover panels for chickens: a cheap tool that can help you. In Poultry Perspectives, pp. 4-6.

Estevez, I. 2009. Behaviour and environmental enrichment in broiler breeders. In Biology of Breeding Poultry, pp. 261-83. CABI publishing, Wallingford, UK.

Fiks-van Niekerk, T. G. C. M., I. C. de Jong, T. Veldkamp, M. M. Van Krimpen and R. A. Van Emous. 2009. Mutliations in poultry. 46 p. Wageningen UR Livestock Research, Lelystad, Report 255.

Fontana, W. A., A. D. Weaver and H. P. Van Krey. 1992. intermittend periods of infertility identified in naturally mated broiler breeder hens. Journal of Applied Poultry Research 1:190-3.

Gentle, M. J. and D. E. F. McKeegan. 2007. Evaluation of the effects of infrared beak trimming in broiler breeder chicks. Veterinary Record 160:145-8.

Heck, A., O. Onagbesan, K. Tona, S. Metayer, J. Putterflam, Y. Jego, J. J. Trevidy, E. Decuypere, J. Williams, M. Picard and V. Bruggeman. 2004. Effects of ad libitum feeding on performance of different strains of broiler breeders. British Poultry Science 45:695-703.

Heerkens, J. L. T., E. Delezie, T. B. Rodenburg, I. Kempen, J. Zoons, B. Ampe and F.A.M. Tuyttens. 2016. Risk factors associated with keel bone and foot pad disorders in laying hens housed in aviary systems. Poultry Science 95: 482-8.

Hiemstra, S. J. and J. Ten Napel. 2013. Study of the impact of genetic selection on the welfare of chickens bred and kept for meat production. $118 \mathrm{p}$. http://ec.europa.eu/food/animals/docs/ aw_practice_farm_broilers_653020_final-report_en.pdf.

Hocking, P. M. 1993. Welfare of broiler breeder and layer females subjected to food and water control during rearing: quantifying the degree of restriction. British Poultry Science 343:53-64.

Hocking, P. M. and R. Bernard. 1993. Evaluation of putative appetite suppressants in the domestic fowl. British Poultry Science 34:393-404.

Hocking, P. M. and R. Bernard. 2000. Effects of the age of male and female broiler breeders on sexual behaviour, fertility and hatchability of eggs. British Poultry Science 41:370-6.

Hocking, P. M. and E. K. M. Jones. 2006. On-farm assessment of environmental enrichment for broiler breeders. British Poultry Science 47:418-25.

Hocking, P. M., M. H. Maxwell and M. A. Mitchell. 1993. Welfare assessment of broiler breeder and layer females subjected to food restriction and limited access to water during rearing. British Poultry Science 34:443-58.

Hocking, P. M., M. H. Maxwell and M. A. Mitchell. 1996. Relationships between the degree of food restriction and welfare indices in broiler breeder females. British Poultry Science 37:263-78.

Hocking, P. M., M. H. Maxwell, G. W. Robertson and M. A. Mitchell. 2002. Welfare assessment of broiler breeders that are food restricted after peak of lay. British Poultry Science 43:5-15.

Hocking, P. M., D. Waddington, M. A. Walker and A. B. Gilbert. 1989. Control of the development of the ovarian follicular hierarchy in broiler breeder pullets by food restriction during rearing. British Poultry Science 30:161-74. 
Hocking, P. M., V. Zaczek, E. K. M. Jones and M. G. McLeod. 2004. Different concentrations and sources of dietary fibre may improve the welfare of female broiler breeders. British Poultry Science 45:9-19.

Horne, P. L. M. and N. Bondt. 2014. Competitiveness of the EU poultry meat sector. 46 p. LEI Wageningen UR, Wageningen, Report nr LEI 2014-038.

Hubbard, undated. Guide parent stock. http://www.hubbardbreeders.com/media/guide_ps_ classic_08_01_2016_imp_051137500_1634_22012016.pdf (Accessed date 24 March 2016).

Jones, E. K. M. and N. B. Prescott. 2000. Visual cues used in the choice of mate by fowl and their potential importance for the breeder industry. World's Poultry Science Journal 56:127-38.

Jones, E. K. M., N. B. Prescott, P. Cook, R. P. White and C. M. Wathes. 2001. Ultraviolet light and mating behaviour in domestic broiler breeders. British Poultry Science 42:23-32.

Jones, E. K. M., V. Zaczek, M. McLeod and P. M. Hocking. 2004. Genotype, dietary manipulation and food allocation affect indices of welfare in broiler breeders. British Poultry Science 45:725-37.

Leeson, S. and J. D. Summers. 2000. Broiler Breeder Production. Unviersity Books, Guelph, Canada.

Leone, E. H. and I. Estevez. 2008. Economic and welfare benefits of environmental enrichment for broiler breeders. Poultry Science 87:14-21.

Leone, E. H., I. Estevez and M. C. Christman. 2007. Environmental complexity and group size: Immediate effects on use of space by domestic fowl. Applied Animal Behaviour Science 102:39-52.

Mench, J. A. 2002. Broiler breeders: feed restriction and welfare. World's Poultry Science Journal 58:23-30.

Millman, S. T. and I. J. H. Duncan. 2000a. Effect of male-to-male aggressiveness and feed-restriction during rearing on sexual behaviour and aggressiveness towards females by male domestic fowl. Applied Animal Behaviour Science 70:63-82.

Millman, S. T. and I. J. H. Duncan. 2000b. Strain differences in aggressiveness of male domestic fowl in response to a male model. Applied Animal Behaviour Science 66:217-33.

Millman, S. T., I. J. H. Duncan and T. M. Widowski. 2000. Male broiler breeder fowl display high levels of aggression toward females. Poultry Science 79:1233-41.

Moradi, S., M. Zaghari, M. Shivazad, R. Osfoori and M. Mardi. 2013. Response of female broiler breeders to qualitative feed restriction with inclusion of soluble and insoluble fiber sources. Journal of Applied Poultry Research 22:370-81.

Morrissey, K. L. H., T. Widowski, S. Leeson, V. Sandilands, A. Arnone and S. Torrey. 2014a. The effect of dietary alterations during rearing on feather condition in broiler breeder females. Poultry Science 93:1636-43.

Morrissey, K. L. H., T. Widowski, S. Leeson, V. Sandilands, A. Arnone and S. Torrey. 2014b. The effect of dietary alterations during rearing on growth, productivity, and behavior in broiler breeder females. Poultry Science 93:285-95.

Nielsen, B. L., K. Thodberg, J. Malmkvist and S. Steenfeldt. 2011. Proportion of insoluble fibre in the diet affects behaviour and hunger in broiler breeders growing at similar rates. Animal 5:1247-58.

Renema, R. A., M. E. Rustad and F. E. Robinson. 2007. Implications of changes to commercial broiler and broiler breeder body weight targets over the past 30 years. World's Poultry Science Journal 63:457-72.

Sandilands, V., B. J. Tolkamp and I. Kyriazakis. 2005. Behaviour of food restricted broilers during rearing and lay - effects of an alternative feeding method. Physiology \& Behavior 85:115-23.

Sandilands, V., B. J. Tolkamp, C. J. Savory and I. Kyriazakis. 2006. Behaviour and welfare of broiler breeders fed qualitatively restricted diets during rearing: Are there viable alternatives to quantitative restriction? Applied Animal Behaviour Science 96:53-67.

Savory, C. J. and J.-M. Lariviere. 2000. Effects of qualitative and quantitative food restriction treatments on feeding motivational state and general activity level of growing broiler breeders. Applied Animal Behaviour Science 69:135-47.

Savory, C. J. and J. S. Mann. 1997. Is there a role for corticosterone in expression of abnormal behaviour in restricted-fed fowls? Physiology \& Behavior 62:7-13. 
Savory, C. J. and K. Maros. 1993. Influence of degree of food restriction, age and time of day on behaviour of broiler breeder chickens. Behavioural Processes 29:179-90.

Savory, C. J., K. Maros and S. M. Rutter. 1993. Assessment of hunger in growing broiler breeders in relation to a commercial restricted feeding programme. Animal Welfare 2:131-52.

Savory, C. J., E. Seawright and A. Watson. 1992. Stereotyped behaviour in broiler breeders in relation to husbandry and opiod receptor blockade. Applied Animal Behaviour Science 32:349-60.

Savory, C. J., F. A. M. Tuyttens and J. S. Mann. 1996. Temporal patterning of oral stereotypies in restricted-fed fowls: 2 . influece of meal frequency and meal size. International Journal of Comparative Psychology 9:140-58.

Tolkamp, B. J., V. Sandilands and I. Kyriazakis. 2005. Effects of qualitative feed restriction during rearing on the performance of broiler breeders during rearing and lay. Poultry Science 84:1286-93.

van der Waaij, E. H., H. van den Brand, J. A. M. van Arendonk and B. Kemp. 2011. Effect of match or mismatch of maternal-offspring nutritional environment on the development of offspring in broiler chickens. Animal 5:741-8.

Van Emous, R. A. and I. C. De Jong. 2013. Promising management measures to solve the major welfare problems in broiler breeders. Proceedings 2nd International Poultry Meat Congress Antalya (Turkey).

Van Emous, R. A. 2010. Quality Time ${ }^{\circledR}$; an innovative housing concept for broiler breeders. In Proceedings of of the 2 nd International symposium. Highlights in nutrition and welfare in poultry production. Wageningen, The Netherlands, pp. 37-44.

van Emous, R. A., R. Kwakkel, M. van Krimpen and W. Hendriks. 2014. Effects of growth pattern and dietary protein level during rearing on feed intake, eating time, eating rate, behavior, plasma corticosterone concentration, and feather cover in broiler breeder females during the rearing and laying period. Applied Animal Behaviour Science 150:44-54.

van Emous, R. A., R. Kwakkel, M. van Krimpen and W. Hendriks. 2015a. Effects of different dietary protein levels during rearing and different dietary energy levels during lay on behaviour and feather cover in broiler breeder females. Applied Animal Behaviour Science 168:45-55.

van Emous, R. A., R. P. Kwakkel, M. M. van Krimpen, H. van den Brand and W. H. Hendriks. 2015b. Effects of growth patterns and dietary protein levels during rearing of broiler breeders on fertility, hatchability, embryonic mortality, and offspring performance. Poultry Science 94:681-91.

Wachenfelt, E. and E. Berndson. 2014. Usge of perches in meat fowlsSveriges lantbruksuniversitet Fakulteten för landskapsarkitektur, trädgårds- och växtproduktionsvetenskap.

Yassin, H., A. G. J. Velthuis, M. Boerjan and J. van Riel. 2009. Field study on broilers' first-week mortality. Poultry Science 88:798-804.

Zuidhof, M. J., D. E. Holm, R. A. Renema, M. A. Jalal and F. E. Robinson. 2015. Effects of broiler breeder management on pullet body weight and carcass uniformity. Poultry Science 94:1389-97.

Zuidhof, M. J., R. A. Renema and F. E. Robinson. 2007. Reproductive efficiency and metabolism of female broiler breeders as affected by genotype, feed allocation, and age at photostimulation. 3. Reproductive efficiency. Poultry Science 86:2278-86.

Zuidhof, M. J., B. L. Schneider, V. L. Carney, D. R. Korver and F. E. Robinson. 2014. Growth, efficiency, and yield of commercial broilers from 1957, 1978, and 2005. Poultry Science 93:2970-82. 
